\title{
How dancing, singing and playing shape the ethnographer: research with children in a Balinese dance studio
}

\author{
By Jonathan McIntosh (Queen's University Belfast)
}

In this article I contribute to the debate on research methods in ethnomusicology. To do this I illustrate how active engagement in the activities and learning processes of children better enables the ethnographer to gain insights into children's musical worlds. This is borne out of my research concerning children's practice and performance of dance, music and song in South-central Bali. The principle aim of my research was to examine the role of music and dance in the everyday lives of Balinese children. This was achieved through an investigation of children's learning and performance of ceremonial and secular traditional dance forms, children's songs and games, and children's disco dance performances. Taking Corsaro's (1985) 'reactive approach', which is responding to or following the children's wishes as my key fieldwork strategy, I show how I developed a basic practical knowledge of Balinese dance and children's songs. This knowledge then made it easier for me to communicate with children and for them to invite me to participate in their music, dance and play activities. I demonstrate that such occasions were beneficial to my research work, because in allowing me to gain insights into their learning of traditional dance and to learn about their songs and games, my potential child-informants also had an opportunity to discover who I was and why I wanted to learn from them.

\section{Introduction}

The ethnomusicologist Bruno Nettl (1983:249) describes fieldwork as,

the most personal part of the job, the part that cannot really be taught, which each must learn on his [or her] own, finding ways of mediating between his personality and its strengths and weaknesses, confidence and timidity, and the individuals whose shared beliefs he will interpret.

Above Nettl discusses how ethnomusicologists learn by being in the field. In this article, I discuss how I conducted fieldwork with children in a dance studio (sanggar tari) in Bali, Indonesia, by describing how dancing, singing and playing with children became a vital part of my research methodology. The aim of my research was to investigate children's practice and performance of their dance, music and song activities. This was achieved through an examination of children's learning and performance of ceremonial and secular traditional dance forms, children's songs and games, and the role of popular music in children's lives.

It seems ironic that despite a substantial literature available relating to Balinese music and dance, little empirical data exists concerning the ethnomusicological study of Balinese children. Although notable ethnomusicologists, including McPhee (1970), Wallis (1979), Sanger (1986), Tenzer (1998) and Harnish (2001a), refer to children's music and dance activities, their research is not child-focused. My research is intended to contribute to the literature concerning the ethnomusicological study of 
children in Bali by providing material specifically relating to children and their musical activities. During fieldwork, I learned to dance with children and perform in front of Balinese audiences, play and perform gamelan (an orchestra mainly comprising metallophones, gongs, cymbals and drums), sing children's songs in Balinese and Indonesian and play children's games. Through these activities I progressively improved my ability to interact with children. Moreover, my willingness to participate and to make a fool of myself on a regular basis provided children with frequent opportunities to learn about an inept foreign ethnographer who wished to learn from and with them. As an ethnographer I wanted children to tell me about the various dances, musics and songs that played an important role in their lives. This was only made possible through the reciprocal relationship developed between myself and the children with whom I worked. Learning about one another in this way gradually made it possible for me to gain access to child-informants and enabled me to gather more detailed ethnographic data concerning children and their musical activities.

This article takes the reader through some of the ways in which I conducted research with children in Bali. First, I introduce the reader to phenomenology and how ethnomusicologists have used this approach in their fieldwork. Second, I outline three possible methodological approaches used by other scholars when conducting fieldwork with children. Lastly, I move on to discuss the role of dancing, singing and playing as methods for my research.

\section{The application of phenomenology in ethnomusicological research}

I adopted a phenomenological approach to try and gain insights into children's musical worlds. Phenomenology is a method of philosophising characterised by a number of themes rather than a strict proscriptive or systematic investigation, and is grounded in experiencing phenomena as they present themselves to people. People, in the sense of individual self-awareness, constantly experience their surroundings as phenomena - this is essentially what Heidegger (1962) meant by 'being-in-the-world' (cf. Moran 2000:13) - which must be understood in the manner that phenomena present themselves rather than as component parts of a structure, in causal terms, or with any comment on their ontological status. This echoes Merleau-Ponty who discusses the necessity and primacy of describing experience rather than explaining or analysing it (Merleau-Ponty 2004:viii, Moran 2000:14).

One of the central concerns of phenomenology is the possibility of understanding the subjective experiences of others, yet the difficulties inherent in this are manifold. Since each person is an experiencing subject in their own right, they can relate to the experiences of others, though it may be impossible to replicate these exactly. Phenomenology advocates the use of empathy in this attempt to position oneself closer to the experiencing others:
in the main, we do not construct a reality solely on the basis of private encounters with exemplars of natural states. Most of our approaches to the world are mediated through negotiation with others. (Bruner 1986:93)

As a research method, phenomenology has allowed ethnomusicologists to try and sympathetically understand how individuals experience music on their own terms. By adopting phenomenological practices in relation to the study of musical expressions, ethnomusicologists try to interpret, through empathy, how individuals' musical 
experiences of 'being-in-the-world' are understood, articulated and socially constructed (Berger and Luckmann 1991:15). However, the difficulty in understanding the experiences of those we study is obvious. We cannot experience the experiences of others. Nevertheless, phenomenology, by means of the reflexive 'hermeneutic arc' (Ricoeur 1981:164), has been useful in allowing the ethnomusicologist to reflect on his or her own learning opportunities in order to empathise with the experiences of others.

In ethnomusicology, the core issue of how the individual gains a sense of who and what they are, is regarded as central to understanding the musical concepts of individuals. To ethnomusicologists, as well as phenomenologists, human beings embody knowledge through their encounters with the world. Therefore, phenomenology allows ethnomusicologists to comprehend how musical 'expressions are people's articulations, formulations and representations of their own experience' (Bruner 1986:9). By examining how individuals experience, interact with and perceive the phenomenon of music, ethnomusicologists hope to gain insights into the musical experiences of others. Understanding musical experience qua experience is the ethnomusicologist's aim.

Paul Ricoeur's model of the 'hermeneutic arc' (1981:164) has been adopted by several ethnomusicologists, most notably Rice (1994) in his study of the musical experience of musicians in Bulgaria (other notable studies in ethnomusicology influenced by phenomenology include Harnish 2001b, Downey 2002 and Stone 1982). The hermeneutic arc represents a process through which consciousness is realised by reflecting upon experience and then expressing that understanding through text. From Ricoeur's model, Rice interprets three main steps to the application of the hermeneutic arc within ethnomusicology. These steps are (1) pre-understanding, (2) distanciation, and (3) new understanding. Firstly, the arc begins with preunderstandings of music, either as a performer or as a listener who finds it coherent. Secondly, distanciation occurs. This is a process whereby the individual stands back and metaphorically looks at him or herself from a distance. This is essential to the process of reflection. Finally, after passing through a process of distanciation and interpretation, an individual comes to a new understanding of musical experience. By means of this process, and by utilising hermeneutics, Rice (1994:4) claims that the understanding of musical experience leads to an expansion of an individual's musical horizons (Gadamer 1986:273, cited in Rice 1994:320n4).

Having briefly outlined phenomenology and its applications within ethnomusicology, I will now move on to discuss my own and other researchers' approaches concerning participant observation with children.

\section{Approaches to participant observation with children}

I began with a phenomenological approach to fieldwork, drawing upon a research model developed by the USA sociologist William Corsaro that has been successfully used in fieldwork with children in the USA (Corsaro 1985) and Italy (Corsaro and Molinari 2000). The premise of Corsaro's 'reactive approach' is that the best way to gain access to children's lives is to let them define and shape the ethnographer. Instead of instigating or imposing a particular way of working upon informants, Corsaro advocates responding to or following children's wishes as a fieldwork 
method. This then allows the ethnographer to gain access to children's worlds without predefining his or her role in the field.

One of the most important aspects of this approach is that it also attempts to blur traditional adult-child relationships by placing children in a more powerful and authoritative position in the research process. Since this research method has proved successful regarding cross-cultural fieldwork with children (Corsaro and Molinari 2000), as a foreign ethnographer, I believed that it would better allow me to empathise with children in the Balinese context. As far as I am aware, my study is the first to apply Corsaro's approach to the ethnographic study of children in Bali.

Throughout my fieldwork, I adopted Corsaro's 'reactive approach' since it did not impose any particular way of working upon informants or the researcher. I hoped that it would provide me with an initial avenue into children's music and dance activities, where I would be seen as a less powerful or even an incompetent adult whom children would teach. The benefit of being incompetent was that it blurred adult-child roles and relationships, which better enabled me to elicit responses from children. This would not have been possible if I had entered the field with the intention of trying to master a craft or practice, since it would only have served to reinforce traditional adult-child roles in the Balinese performing arts, where children are regarded as apprentices and adults are respected as teachers and performers. By encouraging children to train me, I was better able to access and readily participate in their activities.

My participation in children's play activities contravened expected norms of Balinese adult-child relations, since adults do not usually engage with children in dance and play-songs. In Bali, adults sometimes initiate play with and sing to children, but I was someone children could control in their play; they agreed to manipulate and play with me, whereas Balinese adults usually play with, and exercise power over, children. I have found Ingold's definition of 'play' helpful when considering my role in playing with children. Ingold (1994:343) defines play as:

a creative dissembling of conventional orders, blurring the distinction between the real and the unreal, and in that way opening up a space of pure potential, of the boundless possibilities of being.

My involvement in play not only dissembled traditional adult-child roles but also allowed children the opportunity to re-evaluate their expectations of play and to reorient me as someone who could play, not someone who initiated play. Finally, as an anomaly - a cultural outsider with limited language and dance skills - I was invited by children to participate in, and become part of, their make-believe play-worlds.

According to Graue and Walsh (1998:16), 'the goal of working with children should be to explain facts while preserving the manifold richness of their lives'. In response to this call, social science research has moved away from the concept of the child as object and instead focuses upon positioning the child as a subject or social actor (Christensen and James 2000:3). As a result, children's perspectives are now regarded as valid in their own right because they provide useful insights into their social construction of reality (Berger and Luckman 1991:33). In as much as researchers can transcend age and authority boundaries, children may offer access to their 'hidden' culture (Knapp and Knapp 1976, Llewellyn 1980). This also echoes the general trend in the social sciences away from understanding people through their structural positions. 
However, participant observation with children involves different problems than with adults. Fine and Sandstrom (1988:75) suggest that these problems may be minimised by what they term the 'three R's' of participant observation with children: responsibility, respect, and reflection, where 'the phenomenological validity of attempting to understand the life of a child on his or her own terms is essential' (Fine and Sandstrom 1988:76). Graue and Walsh (1998:xiv) write that finding out about children is 'exceptionally difficult' and that '[p]hysical, social, cognitive, and political distances between the adult [researcher] and the child make their relationship very different from relationships with adults'. In this way, a researcher can never become a child when conducting research with children. He or she always remains a 'very definite and readily identifiable "other" (Graue and Walsh 1998:xiv).

Nevertheless, researchers have employed various methods and approaches to try and gain access to children's worlds. According to Fine and Sandstrom (1988:38), those who wish to conduct research with children tend to position themselves in one of three possible ways. One approach is to enter the field satisfied with an adult's role and to learn what one can while using traditional relationships of parental and adult authority as central to how meaning is constructed (see Sluckin 1981). Another approach is to go 'native' (Fine and Sandstrom 1988:40) and position oneself as an adult-child attempting to become a child through role-play, i.e. the adult ethnographer acts like a child in an attempt to try and become childlike. Although such an approach would seem to offer a unique perspective from which to investigate children's worlds, it still imposes a particular way of conducting research with children, where childinformants have little or no say in how the relationship between them and the ethnographer is formulated. An example of this approach can be seen in the work of Laerke (1998), who conducted fieldwork with children in an English primary school. Throughout her research, Laerke attempted to place herself as a child as much as possible by dressing and behaving in a manner that was similar to the children with whom she worked (also see Mandell 1988).

I neither chose to adopt a traditional adult-child, nor a 'native' approach during my research. The first approach enforces existing notions of adult-child roles and relationships and I consider the second approach to be patronising towards children because it purposefully presents a false version of the ethnographer to his or her prospective informants. It seems to assume, somewhat naively, that by literally attempting to disguise the concept of the adult-child relationship an ethnographer can gain access to children's worlds. Although in a metaphorical sense, ethnographers enter 'the field as children' and in time their 'insights and competences mature' (Whitehouse 2001:219), they should not be under any illusion concerning the possibilities of becoming like a child, nor about becoming fully integrated members of the community as a result of their fieldwork.

Thirdly, researchers have resisted adopting a prescribed role and allowed children to formulate an appropriate position for them (Corsaro 1985:28, Corsaro and Molinari 2000). Here, children should react to the presence of the researcher rather than the researcher taking an active role in establishing relationships and defining boundaries for the research. Graue and Walsh (1998:107) consider Corsaro's strategy to be 'not one of acting like a child but rather of not acting like an adult'. Moreover, Corsaro and Molinari (2000:183) argue that the strengths of cross-cultural ethnographies of children are due to the fact that the foreign ethnographer is often seen as a less threatening adult by children and young people. This was an important element in my 
research, because as a foreigner who was 'not being an adult', I was invited by children to become involved in their activities.

In the remainder of this article I show, by means of two ethnographic examples, that the best way to gain access to children's worlds is to let children define the ethnographer's role. However, defining a role is problematic for a range of reasons. In play, children assumed power over me and I allowed myself to be led. Outside of play contexts, they accorded me the authority due to an adult. With younger boys and girls, and older boys, this transfer of power was more easily achieved than with girls aged nine years and above. This can be explained if one considers that, at this age, Balinese girls tend to become aware of their physical development and so they tended to be shy towards me. However, before I discuss my fieldwork with children, I will first introduce the site of my research.

\section{Fieldwork with children in a Balinese dance studio}

During my fieldwork year (October 2003 to October 2004), the majority of my research (from January to October 2004) was conducted with children at a dance studio (sanggar tari in Indonesian) in the village of Keramas, in the district of Gianyar, in South-central Bali. The dance studio is called the Mumbul Sari Dance Studio (Sanggar Tari Mumbul Sari). In Balinese mumbul means 'spring or water falling into a small pond', and sari means 'pollen' or 'flower'. Here, I will simply refer to Sanggar Tari Mumbul Sari as 'the sanggar', since this was how the children and the dance teachers referred to it. The sanggar was established in 1993 by two dancers, I Wayan Rawit and his wife, Ni Luh Happy Pariamini. 'Happy' is Ni Luh Happy Pariamini's first name - equivalent to the same word in the phrase 'Happy Birthday' - and in this article I refer to I Wayan Rawit as Wayan and Ni Luh Happy Pariamini as Happy. Both Wayan and Happy are respected performers and dance teachers in the local, as well as the wider, area. Wayan and Happy have three daughters - Putu-Letsu aged eight, Kadek Imon aged six, and Komang who was eighteen months. They live with Wayan's mother and father, whom the children referred to as granny (dadong) and grandfather (pekak or kak), Happy's younger brother Roy and other members of Wayan's extended family. During the time of my research, approximately 150 children from Keramas and other surrounding villages attended dance lessons at the sanggar.

Dance, music and drama are integral to Balinese society and are performed for ceremonial and entertainment purposes. Ceremonial genres of performance are given as offerings to the deities of the Bali-Hindu religion. However, secular genres are performed to entertain deities and human beings. Both types of performance are essential elements of village and regional temple festivals: ceremonial performances tend to take place in the inner courtyard (jeroan) of a temple (pura), whereas secular performances are mostly held in the outer courtyard of a temple (jaba). Due to its central importance in Balinese society, learning to dance remains a popular activity amongst Balinese children, though not all children choose to engage in dance lessons.

At the sanggar, approximately three times more girls than boys were officially enrolled for dance lessons. This ratio was similar to that of other dance studios in the surrounding area, where boys were always in the minority. However, this gender imbalance more readily reflects traditional roles for Balinese children. Girls are expected to engage in traditional female activities, such as helping at home with the 
washing, cooking, cleaning, and making of religious offerings. Therefore, girls tend to stay near to their family compounds and do not wander or play far from home. In contrast, boys from the age of eight years old tend to wander or bicycle through a village, and as teenagers (or younger) they learn to drive a motorcycle and travel outside of the village. I do not want to imply that dancing is regarded as a female activity. However, my observations suggest that more girls than boys are involved in learning traditional dance at the current time, and that this is fast becoming a general trend across the island. In addition, multimedia influences, such as television, radio, computer games and the influence of various forms of Balinese, Indonesian and global popular musics, mean that children have a wider choice of activities in which to participate.

In spite of the competition between media and traditional activities, all the children at the sanggar attend lessons of their own free will, and although the primary reason for attending lessons is to learn how to dance, it also provides an important social opportunity for children to meet up and talk with friends and to play games between rehearsals. Only the youngest children up to the age of six are accompanied to the sanggar by a parent or an older sibling. The majority of children either walk or bicycle, alone or with friends, to dance lessons.

Normally, Balinese children start to learn to dance from the age of four or five. The children who attended the sanggar during the time of my fieldwork ranged from four to fourteen years old. To attend the sanggar each child must pay a small fee that covers the cost of their tuition and that also contributes towards the maintenance and purchase of costumes, among other things. Every child pays Rp 5,000 (approximately 30 pence) per month. (This was relatively cheap when compared to other dance studios in Denpasar, the capital of the island, and in the Southern tourist resort of

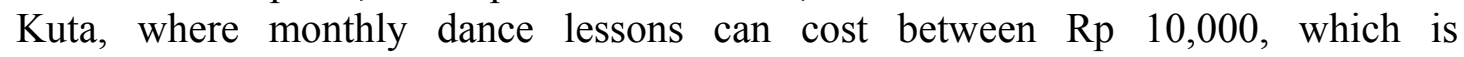
approximately 60 pence, and $\mathrm{Rp} 20,000$, approximately £1.20). The sanggar is a privately-run arts organisation. Two weekly dance rehearsals are held on Tuesday afternoons, from 3 to $5 \mathrm{pm}$, and on Sunday mornings, from 8 to $10.30 \mathrm{am}$. The children from the sanggar regularly perform for ceremonial and secular occasions in the village as well as further afield. When asked to do so, teachers allocate additional rehearsal time and children are expected to attend. All rehearsals take place in a large, open pavilion (wantilan) in the family compound owned by the dance teachers. Wayan and Happy both teach boys and girls although Happy is responsible for the majority of the teaching at the sanggar.

Unlike Balinese children's songs, there is no equivalent category of children's dances in Bali. Instead, children learn adult dances. Traditionally, dance is taught from teacher to student using a method that emphasises (1) imitation, (2) manipulation, and (3) kinaesthetic transfer. A student first learns to dance by imitating the movements of his or her dance teacher. Once a student has embodied and memorised the choreographic outline of a dance, or a section of it, by means of imitation, the teacher then starts to manipulate the student's body, moulding and repositioning it into the correct positions for a dance while also ensuring that movements are executed in the appropriate performance style. To do this, the teacher will frequently take hold of a student by wrapping his or her arms around those of the student. He or she will also use his or her knees and feet to indicate to a student the most appropriate way to move in time with the music. Through this process the teacher's style of dancing and interpretation is kinaesthetically transferred to the student. These transfers encapsulate the transmission of bodily knowledge from the teacher to the student and are regarded 
as the most efficient way for a teacher physically to impart his or her style of dancing 'into' a student's body. This teaching method is the most effective way for teachers to exercise power over children's bodies in the sanggar.

Although the practice described above is still regarded as the most efficient teaching method in Bali, in dance studios it has been adapted to facilitate the teaching of dance to a large number of students at any one time. Children first of all learn to dance in large groups. These groups are divided according to gender and ability. When teaching a large group of children, a teacher simply does not have the time to work with each student individually. As a result, methods of teaching have been developed that incorporate elements of traditional practice with more recent analytical techniques. These adapted methods involve less demonstration and manipulation by the teacher than traditional teaching practices do, and are heavily dependent instead upon verbal instructions and corrections. Therefore, it takes children longer to learn a dance in a large group according to the adapted teaching method than it does, traditionally, when receiving individual tuition.

At dance lessons, children practise ceremonial dances that they will perform at village temple ceremonies as acts of religious devotion known as ngayah. They also learn popular dances from the Balinese secular canon. These include ensemble and solo dances that are performed for entertainment purposes at temples and community halls (balé banjar), and for inclusion in tourist performances. Dance teachers decide when children are ready to perform in public. The children are then judged by those present at a performance according to their age and technical proficiency. The aim of these performances is not for children to present a technically clean performance, especially when they are inexperienced dancers. Instead, these performances are viewed as opportunities for children to gain valuable performance experience that will aid their development as dancers.

Before I became directly involved with Sanggar Tari Mumbul Sari, I studied Balinese dance with Happy in the nearby village of Ubud, where she teaches dance to children at another sanggar. For three months I studied a male dance called Baris Tunggal. This is a solo male dance learned by all boys because it incorporates the rudiments of all male Balinese dance styles. During this time, I experienced the aches and pains that the body endures and eventually comes to accept as part of the learning experience, and my knowledge concerning the unique and inseparable relationship between Balinese music and dance deepened. I also learned how to decode the verbal corrections sung, spoken, and sometimes shouted, at me by my teacher by using my body in relation to the musical accompaniment of the Baris Tunggal dance. After I had memorised the 15 minutes of the dance, and knowing that I wanted to work with children, Happy invited me to travel to her sanggar Keramas. There, I continued with my dance lessons and attended the children's dance rehearsals at her home. Had I not first learned how to dance before working in Keramas, my awareness and understanding of the activities at the sanggar would have been limited and, more importantly, I would not have possessed the skills that enabled me to join in with children in their dance lessons when they later invited me to do so.

\section{Participating with children in dance rehearsals}

During one of the children's dance lessons I attended at Happy's home in Keramas, I sat on the raised concrete stage at the far end of the dance pavilion to observe the 
children's dance rehearsal. A group of young girls were practising Panyembrama, a well-known dance performed by females to welcome deities and visitors to secular performances. I watched as the rehearsal unfolded in front of me. Suddenly, a small boy aged about ten who had been sitting beside me for perhaps 30 minutes told me, in Indonesian, that his name was Putu. 'What's your name?' he asked. I told him that my name was Jonathan and he tried to repeat it back to me, but he could not pronounce the 'th' sound (this sound does not exist in Indonesian and, as a result, it was difficult for the children to pronounce it). 'Jon-a-tan?', he said nervously, the intonation of his voice rising towards the end of my name. 'Yes,' I answered. No sooner had I replied when Putu turned around to the other children and shouted, in a mixture of low Balinese and Indonesian, 'The tamu is called Jon-a-tan!' (The Indonesian word tamu is a generic term for a visitor or guest, but it is mainly used by the Balinese to refer to a tourist, especially a white tourist.) I heard my name being repeated in whispered tones all round the pavilion by those children who were not dancing at present. Then followed a flood of questions from Putu: 'How old are you? Where do you come from? Why are you here? Do you own your motorbike? How much did you pay for it? What are you writing in your notebook?' I tried as best as I could to answer his questions, but when he had had enough of my stumbling Indonesian he got up, walked a little away from me and sat down with the other boys.

By this time the girls had finished rehearsing and it was the turn of the boys to practise one of their dances. They all walked to the back of the pavilion and organised themselves into four lines whilst Happy searched for the correct cassette tape to provide the musical accompaniment to the dance. There was a short moment of silence as the boys waited patiently for the music to start. During this time, Putu shouted, 'Guru (teacher), will the tamu dance with us?' At first I thought Putu's request was a joke. All of a sudden I froze and looked at the children. They all stared straight back at me, their eyes opened wide with expectation. The momentary silence was broken by Happy. She turned to me and uttered, 'Go', nodding her head towards the group of boys, before turning her attention back to the cassette player. I did not know what to do. I was not ready to dance. I did not know enough and, more importantly, I only knew one dance and I could tell by the music as it started that this was not it. However, there was no choice. With everyone staring at me, I slowly got up and made my way to the back of the pavilion. As I walked, a gabble of Balinese broke out amongst the other children who had all gathered to watch-'The tamu is going to dance!'

\section{New reactive roles}

When chronicling his experiences among the Warlpiri of the Tanami Desert in Central Australia, Jackson (1995:21) writes,

...fieldwork cannot be willed into happening. Inevitably, it proceeds by fits and starts. Anxieties and doubts beset you, no matter how good your language skills, how thorough your background reading, how extensive your ethnographic experience in other cultures. This is because the savoir faire on which your social survival and sense of self-worth depend stems not from any abstract understanding but from direct familiarity with a body of practical knowledge which informs every aspect of everyday life and can only be acquired gradually through trial and error. 
There is no doubt in my mind that my ability and willingness to dance, and to react to new roles designated to me by children, was the key to my fieldwork. Dancing enabled me to gain insights into the learning experiences of children, especially when they talked with me concerning the manipulation of their bodies by their dance teacher during lessons. Through my own experiences, I was able to empathise with the pain they sometimes felt as part of the apprenticeship process and it also allowed me to gain a deeper understanding of how children conceive of the inseparable relationship between music and dance in the Balinese context. By dancing with children in an environment that was generally assumed by children and adults alike to be a place where children learned to dance, I blurred traditional Balinese adult-child relationships. In this sense, and according to Ingold (1994), my ability to dance was a form of play that not only enabled my participation with children at the sanggar, but encouraged them to teach me. Although in the episode described above it was Happy who sanctioned my participation in the rehearsal, the encounter was initiated by one of the children.

For the children, the experience of having a white, adult foreigner in their dance class was real, but surreal at the same time. It would have been highly unusual for an adult Balinese man to join in with a children's dance rehearsal like this, since in Keramas at least, one is expected to learn the basics of dance while still a child. I did exactly the opposite and learned to dance as an adult. In doing so, I blurred the children's expectations of adult-child relationships; physically, I was an adult, but my dance ability and knowledge paled in comparison to that of all but the youngest of children at the sanggar. To begin with, the children and their parents laughed at my lack of dance skills, but they also took account of the fact that I was a beginner. One child, in particular, helped me by calling out steps and number-sequences that corresponded to the music as I struggled, at the back of the group, to follow the rest of the boys. However, once they saw that I was committed to attending the sanggar, the children came to expect my participation, and if for any reason I was absent from a rehearsal they always enquired as to why I had been unable to attend.

\section{Living in Keramas}

After living in the town of Ubud for the first six months of my research, I chose to move to Keramas. Keramas is approximately a 20 minute motorcycle ride from Ubud. I did this not only to live with my dance teachers, Wayan and Happy, since learning to dance had become a focus of my research, but I hoped that a move to Keramas would be interpreted as a further sign of my commitment to the children who attended the sanggar. At first, small groups of children came to visit me, which allowed me to gain their confidence. During these visits they rummaged through my belongings, looked at photos, reviewed video material, watched DVDs of Harry Potter and Spiderman 2 on my laptop and happily munched my supply of biscuits and sweets. However, despite all their forwardness in searching through my belongings, most of the children remained shy towards me. I participated with them in dance rehearsals but, apart from fleeting conversations in Indonesian, I found it difficult to participate in other activities. This may have been due to the fact that the children spoke Balinese amongst themselves, since it, and not Indonesian, was their first language.

Just as learning the physical skills of dance enabled me to participate in the children's dance lessons, I hoped that moving to Keramas, and being surrounded by spoken Balinese, would help my learning of the language. This did happen and my 
understanding of Balinese slowly improved. Yet throughout the six months I lived there, children and adults always spoke in Indonesian when they wanted to communicate with me. They did this simply because many Balinese automatically expect foreigners to speak Indonesian and not Balinese. However, from time to time, I tried out my limited Balinese with the children at the sanggar and, in return, they played language games with me. In one such game, they would tell me the name of an object in Indonesian and ask me to answer back with the equivalent word in Balinese. For example, the word for 'horse' in Indonesian is kuda but in Balinese it is jaran; similarly, the word for 'river' in Indonesian is sungai but in Balinese it is tukad. The children regarded these quizzes as opportunities to try and catch me out, which inevitably happened sooner rather than later. These games helped me to expand my Balinese vocabulary, and because children initiated them they ensured that they remained in control of the game. This was considerably different from almost every other situation when they were in the presence of an adult, when children were expected to be respectful and subservient.

My moving to Keramas had several other important implications for my research. Up until that time, I commuted daily by motorcycle from Ubud to Keramas. This arrangement, however, meant that I could only attend rehearsals and events that were planned ahead of my arrival. To many of the younger children this meant that I was a white person who arrived at the sanggar and stayed for a few hours, before leaving once more to go back home to Ubud. It was difficult during these times to observe children outside of the sanggar and to be invited to participate in their play activities. Thus, the aim of my decision to move to Keramas was to try and further develop the trust of my child-informants. When I moved to the village, I was no longer the white foreigner who arrived and then left; I became the foreigner who lived at the sanggar.

Living in Keramas meant that I had daily contact with children, which enabled me to develop personal ties and relationships with them and their families. More generally, I quickly became integrated into the family of my dance teachers and accustomed to life in a Balinese village. Living with a Balinese family meant that children could see, for example, that I ate the same food as other villagers, and they could also watch me when I washed my clothes in the river. By doing this, I felt I was being more open with the children, and by living in their village I gave them more opportunities to shape me as their ethnographer.

Living with my dance teachers also meant that I could take extra dance lessons to develop my basic dance technique. The children seemed to appreciate the fact that I wanted to try and catch up with them when they had their dance lessons. Occasionally, they came to my dance lessons where they sat and eagerly watched my progress. During these times, when the teacher was not looking, they would offer me advice as to how I could improve a movement or a choreographic sequence. When the children had their lessons, I was present at the sanggar, ready to observe and participate when they invited me to do so. I did not have to worry about commuting to and from Keramas or missing a rehearsal due a flat tyre on my motorcycle, which unfortunately had happened on several occasions previously. Moreover, if there were sudden changes to a rehearsal schedule or a performance, or if the children wanted to come and visit me at the sanggar, being in Keramas meant that I could easily change my plans to participate in or observe these activities. 


\section{Participating in children's play-songs}

One day, not long after moving to Keramas, I walked across the grey, gravel driveway of the sanggar to a small platform (balé) raised slightly off the ground, at the side of the compound. In contrast to the hot, jagged, crunching gravel, the roof over the platform meant that its tiled floor was cool and smooth. From this position, I could hear children playing in the road that ran alongside the sanggar. I sat cross-legged on the floor and opened one of my notebooks containing transcriptions of Balineselanguage children's songs I had recorded and transcribed while living in Ubud. I had not sung them for about a week and I wanted to practise them. After quietly practising a few songs, I turned the page and started to sing a nonsense song about birds, small turtles and the price of mangoes. The song is entitled Curik-curik, 'starlings' (see below).

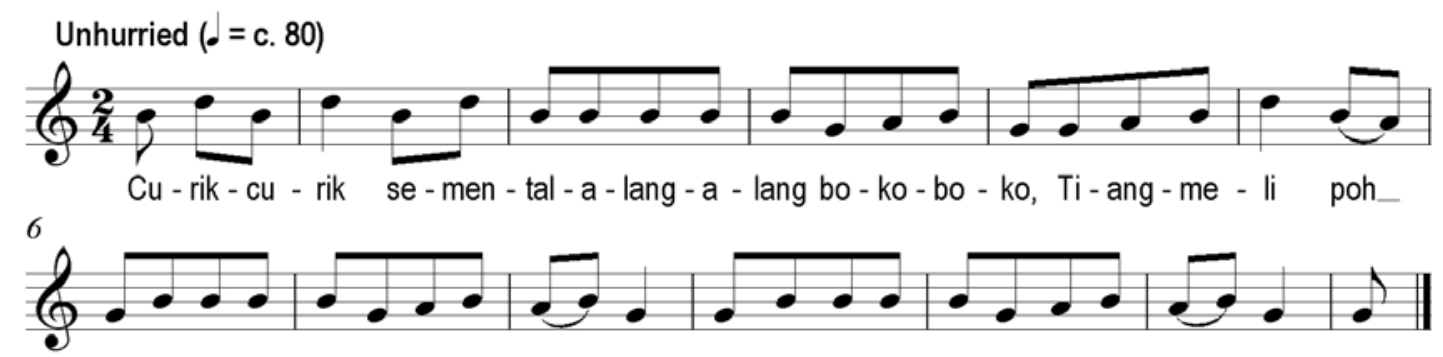

é, A - ji sa - tak a - ji sa - tus_ké - téng, Ma-ra ba - kat a-nak ba - gus_pé - céng.

Curik-curik semental alang-alang boko-boko,

Starlings, ripe fruit, bushes and small turtles,

Tiang meli pohé,

I buy the mangoes,

Aji satak aji satus kéténg,

The prices are two hundred and one hundred,

Mara bakat anak bagus pécéng.

Just got a blind handsome child.

I sang it a few times before the iron gate of the compound swung open, and the children, who had been playing outside, entered. They asked, 'Where did you learn that song?' 'I learnt it when I was living in Ubud,' I replied. 'Do you want to play Curik-curik?' another child asked. Puzzled, I enquired, 'Play? Is there a game with this song?' 'Yes,' they all chorused. 'Of course there is! Come on let's play!' I got up and the children proceeded to teach me the game that accompanied the song, after which I joined in with their playing and singing.

To my surprise, the game itself is remarkably similar to the English children's game Oranges and Lemons, a game I used to play when I was six or seven years old. To 
play Curik-curik, two children hold hands and form an arch. The two children who form the arch secretly decide who is to be either 'apple' (using the English word) or 'mango' (mangga in Indonesian). (Curiously, the children did not use the equivalent Balinese word for mango, poh, used in the song that accompanied the game. This could be because children also played this game at primary school, where Indonesian and not Balinese is the main language used.) The other children go through the arch in a line, circling round and behind it, going through it again and again, singing the song. When the last word of the song is called out, the two children forming the arch lower their arms and catch the child who is underneath. The captured child then has to choose between 'apple' and 'mangga'. After making their choice, the captured child stands behind the child forming the arch, who represents that fruit. When all the children have been caught, the game concludes with a tug of war. The winning team is the one left standing!

Being invited by children to participate in their song-games was another important milestone for my research. My playing and singing Curik-curik with children meant that I was later invited by them to participate in other play activities. Living in Keramas also meant that I was often asked to play with children in the narrow road that ran alongside the sanggar. These occasions then gave me the opportunity to learn the games and actions integral to many Balinese and Indonesian children's songs. In exchange for letting me learn about their songs, I taught the children Englishlanguage song-games. Through my playing and exchange of songs, the children gradually became more comfortable with my presence and soon they asked if I could make audio and video recordings of them so that they could listen to their singing and watch themselves on the television.

By employing a research method that blurred and subverted traditional adult-child relationships, and allowing children to decide whether or not they wanted me to participate in their play activities, I was able to obtain recordings of traditional Balinese songs and recent Indonesian songs composed by children. However, I also think the children who invited me to participate with them in their activities really were doing what they did best by being friendly, creative, inquisitive and competitive. I believe that it would not have been possible to record children singing and playing these songs if I had used traditional relationships of parental and adult authority or role-play as a research method. As illustrated in the example of Curik-curik, it was only through my playing and singing that I was better able to react to their wishes and obtain valuable data for my research.

\section{On shaping the ethnographer}

Kisliuk (1997:24) writes that '[e]thnographers use tactics different from those of travel writers...to define who they are in the "field"'. Before travelling to the field, I did not think that play and my ability to play would become such an important part of my fieldwork methodology. When I first arrived in Bali, there were some occasions where I attempted to develop working relationships with children by initiating play with them. These attempts were made at other sanggar in Ubud before my work at Sanggar Tari Mumbul Sari in Keramas. However, on the majority of these occasions, my attempts failed. In spite of the fact that many children at these other sanggar were curious about my presence at their dance lessons, they did not always want to accept or they refused my invitation to play. This was at a time in my fieldwork when I had just started to dance and I only knew a handful of children's songs. 
The episode described above, in which the children in Keramas taught me how to play the game that accompanied the song Curik-curik, demonstrates that children's dance, music and play activities require learning and skill. By the time I started attending dance rehearsals in Keramas, I had sufficiently developed the necessary skills needed to facilitate my involvement in children's activities. Had I not learnt the rudiments of Balinese dance and a few children's songs before my arrival in Keramas, it would have been difficult for me to achieve the same degree of access to child-informants. In order for ethnographers to participate in work or play with children in any field site, they first have to acquire some of the appropriate knowledge and skills to enable them to do so.

During the six months I lived in Keramas, I developed close relationships with a group of approximately 40 child-informants, aged from five to fourteen years old. As they gradually got to know me, and I them, they spent longer periods of time in my company. In this way I was able to acquire the knowledge and skills needed to participate in children's activities. In another way it meant child-informants quickly developed confidence in me. By choosing to react to or follow children's wishes, I was able to gain entry to a community and to meet the objectives of my research: to find out about the role of music and dance in children's lives. A sign given to me by the children that I had been accepted was when they assigned me a nickname. In Bali, it is common practice for the family and friends of an individual to call an individual by a shortened version of their full name. The children, quickly and somewhat affectionately, shortened my name to 'Jon'. When this occurred, I no longer felt as if I was just the foreign ethnographer, a tamu, called 'Jon-a-tan'.

The children's acceptance of me was also evident in different ways during my fieldwork. On some occasions my role became similar to that of a guardian or an older sibling when children often asked me to accompany them to temple or to particular dance performances. If it was late at night after a temple ceremony, some children asked for a ride home on the back of my motorcycle and I frequently transported them to dance rehearsals and performances outside Keramas. At official dance studio performances, I was the group photographer. At the same events, I was also asked to help apply the children's make-up and assist them in getting dressed in their costumes. These 'non-play' roles prescribed for me by the children meant that they had become accustomed to my behaviour in various contexts. As they became more familiar with me, they also gave me a whole host of other roles that did not necessarily involve play.

\section{Conclusion}

By adopting a reactive methodological approach to my fieldwork, similar to that outlined by Corsaro (1985), I was able to disclose my vulnerability to children and, in turn, they allowed me to become an ethnographer. My inability to dance, my lack of knowledge concerning children's play, and my less than adequate language skills meant that I was quickly defined by children as an 'atypical adult' (Corsaro 1985:29) in the Balinese context. As a result, my playing overturned traditional conventions and blurred notions of real and unreal worlds (Ingold 1994:343). However, the fact that I had acquired some knowledge about dance and children's songs before working at Sanggar Tari Mumbul Sari enabled me to better participate in children's activities. 
I believe Corsaro's method is important because it focuses upon learning from children. Unlike other methods that advocate the acceptance of adult-child relationships or role-play, a reactive approach does not impose upon children ways of working in the research process. In fact, the main strength of this method is that it places children at the centre of the research, since it allows informants to shape the ethnographer. During this process the ethnographer often remains on the periphery, waiting for signs to indicate if his or her informants have accepted him or her.

As a learner and a foreign ethnographer, I allowed everyone, children and adults, to witness my mistakes and to laugh at me, no matter how uncomfortable and disheartening it sometimes made me feel. By remaining open and honest with the children who chose to work with me, I was gradually incorporated into the world of the sanggar. There not only did I learn from adult teachers, but children also taught me about dance, how to sing and play. This was only possible by encouraging childinformants to teach me. I never tried to become child-like (see Laerke 1998) nor did I attempt to adopt roles children did not ascribe to me. Instead, through my actions and words, I allowed children to decide whether or not they wished to let me work with them (Kisliuk 1997:27).

By working with children through play, I gradually learned how to do research and how to, hopefully, become a proficient ethnographer. During the course of my fieldwork, I realised that no one can actually teach or tell another person how to do fieldwork. Ultimately, fieldworkers must figure things out for themselves while in the field (Jackson 1995:21, Nettl 1983:249), since '[u]nderstanding is less a product of your methodology than your mastery of basic social skills' (Jackson 1995:21). During my fieldwork, I learnt the basic social skills necessary to help me negotiate my role as an ethnographer by participating in dancing, music-making and play activities with children. And by inviting me to participate in their activities, children created opportunities for my work.

\section{References}

Berger, P. and T. Luckmann. 1991 [1966]. The Social Construction of Reality: A Treatise in the Sociology of Knowledge. London: Penguin.

Bruner, E.M. 1986. Experience and its expressions. In The Anthropology of Experience (eds) V.W. Turner and E.M. Bruner, 3-30. Urbana and Chicago: University of Illinois Press.

Christensen, P. and A. James. 2000. Researching children and childhood: cultures of communication. In Research with Children: Perspectives and Practices (eds) P. Christensen and A. James, 1-8. London: Falmer Press.

Corsaro, W.A. 1985. Friendship and Peer Culture in the Early Years. Norwood, NJ: Ablex.

Corsaro, W.A. and L. Molinari. 2000. Entering and observing in children's worlds: a reflection on a longitudal ethnography of early education in Italy. In Research with Children: Perspectives and Practices (eds) P. Christensen and A. James, 179-200. London: Falmer Press.

Downey, G. 2002. Listening to Capoeira: phenomenology, embodiment, and materiality of music. Ethnomusicology 26(3), 487-509. 
Fine, G.A. and K.L. Sandstrom. 1988. Knowing Children: Participant Observation with Minors. Newbury Park, CA: Sage.

Gadamer, H-G. 1986. Truth and Method. New York: Crossroad.

Graue, M.E. and D.J. Walsh. 1998. Studying Children in Context: Theories, Methods, and Ethics. Thousand Oaks, CA and London: Sage.

Harnish, D. 2001a. Indonesia, §II, I. Bali. In The New Grove: Dictionary of Music and Musicans, Vol 12 (eds) S. Sadie and J. Tyrell, 289-308. London: MacMillan Publishers.

. 2001b. A hermeneutical arc in the life of Balinese musician, I Made Lebah. The World of Music 43(1), 21-41.

Heidegger, M. 1962. Being and Time. Translated by J. Macquarrie and E. Robinson. New York: Harper and Row.

Ingold, T. 1994. Introduction to culture. In The Companion Encyclopedia of Anthropology: Humanity, Culture and Social Life (ed.) T. Ingold, 329-349. London and New York: Routledge.

Jackson, M. 1995. At Home in the World. Durham and London: Duke University Press.

Kisliuk, M. 1997. (Un)doing fieldwork: sharing songs, sharing lives. In Shadows in the Field: New Perspectives for Fieldwork in Ethnomusicology (eds) G.F. Barz and T.J. Cooley, 23-44. New York and Oxford: Oxford University Press.

Knapp, M. and H. Knapp. 1976. One Potato, Two Potato...: The Secret Education of American Children. New York: Norton.

Laerke, A. 1998. By means of re-membering: notes on a fieldwork with English children. Anthropology Today 14(1), 3-7.

Llewellyn, M. 1980. Studying girls at school: the implications of confusion. In Schooling for Women's Work (ed.) R. Deem, 42-51. London: Routledge and Kegan Paul.

Mandell, N. 1988. The least-adult role in studying children. Journal of Contemporary Ethnography 16, 433-67.

McPhee, C. 1970 [1939]. Children and music in Bali. In Traditional Balinese Culture (ed.) J. Belo, 212-239. New York and London: Columbia University Press.

Merleau-Ponty, M. 2004 [1964]. The Phenomenology of Perception, translated by C. Smith. London: Routledge.

Moran. D. 2000. An Introduction to Phenomenology. London: Routledge.

Nettl, B. 1983. The Study of Ethnomusicology: Twenty-nine Issues and Concepts. Urbana and Chicago: University of Illinois Press.

Rice, T. 1994. May It Fill Your Soul: Experiencing Bulgarian Music. Chicago: University of Chicago Press.

Ricoeur, P. 1981. Hermeneutics and the Human Sciences (ed.) J.B. Thompson. Cambridge: Cambridge University Press.

Sanger, A. 1986. The Role of Music and Dance in the Social and Cultural Life in Two Balinese Villages. Unpublished Ph.D. dissertation. Queen's University Belfast. 
Sluckin, A. 1981. Growing Up in the Playground. London: Routledge and Kegan Paul.

Stone, R.M. 1982. Let the Inside be Sweet: The Interpretation of Music Event Among the Kpelle of Liberia. Bloomington: Indiana University Press.

Tenzer, M. 1998 [1991]. Balinese Music. Singapore: Periplus Editions.

Wallis, R. 1979. The Voice as a Mode of Cultural Expression in Bali. Unpublished Ph.D. dissertation. The University of Michigan.

Whitehouse, H. 2001. Conclusion. In The Debated Mind: Evolutionary Psychology Versus Ethnography (ed.) H. Whitehouse, 203-223. Oxford: Berg.

\section{About the author}

Jonathan McIntosh is currently completing a $\mathrm{PhD}$ in ethnomusicology in the School of History and Anthropology at Queen's University of Belfast, Northern Ireland, UK. He has conducted fieldwork on children's music and dance in Bali, Indonesia, and in Northern Ireland concerning gamelan and applied ethnomusicology. At QUB, he teaches on both the ethnomusicology and social anthropology programmes. He is director of the Queen's University Balinese gamelan ensemble Gamelan Gong Kebyar Widya Santi (gamelan of knowledge and peace) and a performer of Balinese dance. He can be contacted at jonathanmcintosh@yahoo.com 